\title{
Indicators for maintenance planning based on energy efficiency in heat exchanger networks
}

\author{
Indicadores para la planeación del mantenimiento basado en eficiencia energética \\ en redes de intercambiadores de calor
}

\author{
D. E. Yabrudy-Mercado ; ; B. S. López-Sarria ; J. G. Fajardo-Cuadro iD , C. A. Cardona- \\ Agudelo iD
}

\begin{abstract}
Thanks to the asset management regulations, modern maintenance practices are rapidly getting a more managerial role, and is used to achieve savings and optimize energy use. Therefore, knowing at all times the status of the equipment allows for timely and necessary interventions that generate value to the company, and recover the initial conditions of them. Heat exchanger networks, rather than a productive asset, constitute an energysaving strategy, to have lower fuel costs, emission control, rational use of energy, etc. in the atmospheric furnaces of the crude distillation units, and other units that perform similar processes. Thus, keeping them in their best conditions, most of the time is necessary. In this paper, we propose a methodology for the diagnosis of the equipment of the network, and the maintenance planning justified by the energy efficiency of them and the economic impact of the intervention. In addition, an indicator is presented to provide an economic justification for maintenance interventions, as well as for briefly showing the results of the application of maintenance mainly on efficiency and the use of the KPI J proposed for programming the maintenance schedule of some of the equipment (pilot test) of the heat exchanger network under study. The methodology developed uses real operation values, and its results provided savings up to USD 150,000.
\end{abstract}

Index Terms - Crude distillation unit, efficiency centered maintenance, preheat train, rational usage of energy, refineries.

Resumen-Gracias a las normativas de gestión de activos, Las practicas modernas de mantenimiento están asumiendo cada vez un rol más gerencial, y siendo usadas para lograr ahorros y optimizar el uso de la energía. Así las cosas, conocer en todo momento el estado de los equipos mantenidos, permite realizar las intervenciones oportunas $y$ necesarias que generen valor a la empresa, y recuperar las condiciones iniciales de los equipos o cercanas a estas. Las redes de intercambiadores de calor, más que un activo productivo, constituyen una estrategia de ahorro energético, en pro de tener menores costos de combustible, control

This manuscript was sent on October 04, 2019 and accepted on July 14, 2020.This manuscript was presented at the V Simposio Internacional sobre Sistemas Electromecánico SISEM 2019.

D.Yabrudy, candidate for a master's degree in Universidad Tecnológica de Bolívar, Parque Industrial y Tecnológico Carlos Vélez Pombo, Km 1 Vía Turbaco, Cartagena, Colombia. He also is a lecturer in Universidad Antonio Nariño, Av. Crisanto Luque Dg 22 \# 48A - 64, Cartagena, Colombia. (e-mail: dyabrudy62@uan.edu.co,daniel.yabrudy@automatizacion.com.co).

B. Sarria, was with Reficar as a senior engineer, Mamonal Km $10 \mathrm{Cr}$ A Pasacaballo, Cartagena, Colombia. He is now retired, but he continues as an de emisiones, uso racional de la energía, etc. en los hornos atmosféricos de las unidades de destilación de crudo, y otras unidades que realizan procesos similares, por lo que mantenerlos en sus mejores condiciones la mayor parte del tiempo es menester. A continuación, se propone una metodología para el diagnóstico de los equipos de la red, y la planeación del mantenimiento justificada por la eficiencia energética de los equipos y el impacto económico de la intervención. Para esto se presentan a) los indicadores clave de desempeño de los intercambiadores, b) un indicador que sirve como justificación económico-energética de las intervenciones de mantenimiento, c) cronograma de mantenimiento de algunos de los equipos (prueba piloto) de la red de intercambiadores de calor en estudio. La metodología desarrollada utiliza valores reales operación y sus resultados están aplicados logrando ahorros de 150.000 USD.

Palabras claves-Mantenimiento Centrado en Eficiencia, uso racional de la energía, tren de precalentamiento, unidad de destilación de crudo, refinerías.

\section{INTRODUCTION}

$\mathrm{E}$ fficient use of energy becomes more important daily in industries [1]-[3]. , as several devices (or arrays of them) are implemented in processes, looking for better energy use. Heat exchanger networks (HEN) are arrangements of heat exchangers in series or parallel, which allow recovering the thermal energy [4] of products in a crude oil distillation unit. However, factors as aging, operation, properties of crude-oil, among others, affect the energy performance of HEN. Therefore, cleaning and maintenance have to take place, to increase energy performance [5]-[8].

Several studies have been conducted on HEN's energy performance. However, each one of them is very specific regarding conditions in each location, For instance, Zubair et al. [7], [9] carried out a study about performance and economic evaluation of heat exchanger subject to fouling. They

investigator, and independent advisor. (e-mail: bsarria@unitecnologica.edu.co).

J.Fajardo is with the Mechanical Engineering program, Universidad Tecnológica de Bolívar, Parque Industrial y Tecnológico Carlos Vélez Pombo, Km 1 Vía Turbaco, Cartagena, Colombia (jfajardo@utb.edu.co).

C. Cardona, is with Ecopetrol-Reficar, Mamonal Km $10 \mathrm{Cr}$ A Pasacaballo, Cartagena, Colombia. (e-mail: camilo.cardona@ecopetrol.com). 
investigated fouling models found in industry and reported its effect on thermal performance, seeing that before the critical fouling level occurs, the minimal point cost happens.

Georgiadis et al. [5], [6] approached the problem as an optimization one, restricting the issue by the cost and energy using linear programming, showing that the performance of the Heat exchanger decreases with time, and shutdown needs to be done for cleaning and recover it. Smaili et al. [10] attempted for reducing the fouling in refinery heat exchanger networks by using optimal strategies of cleaning throughout optimization algorithms. They observe that some heat exchangers affect the whole HEN performance more than others when their efficiency decreases by fouling, called "key" heat exchangers.

Rodriguez and Smith [8] evaluated the overall heat transfer performance regarding heat duty, fouling resistance, among others, for optimizing operating conditions under the threshold temperature, to avoid fouling presence. They looked up that a mixture between cleaning schedules and modifications on operating conditions is needed, because, it depends on each heat exchanger; however, there are heat exchangers where modification in operating conditions, do not lead to a reduction in the fouling formation. Ishiyama et al. [11] exposed the effects of fouling in the thermal and hydraulic performance on tube side in parallel shell and tube heat exchangers and discovered that including the desalter leads to more efficient scheduling. Waters et al. [12] conclude that is mandatory monitoring the HEN conditions (fouling specifically), to take the appropriate decisions in operation, maintenance, etc., when needed. Caputo et al. [13] attempted to optimize shell and tube heat exchangers through the minimization of life cycle cost. Likewise, other authors have evaluated the performance of HEN. Wang et al. [14], Assis et al. [15], Tian et al. [4], and Biyanto et al. [16] among others [17]-[30], evaluated the performance of HEN too.

In the following sections it is intended (a) to show the maintenance methodology focused on efficiency (b) to propose a KPI called J, which serves as an economic-energy justification for maintenance interventions, (c) to briefly present the results of the application of the maintenance based on efficiency and the use of the KPI J proposed.

\section{MATERIALS AND METHODS}

For developing a HEN diagnostic model, it is necessary to study the behavior of KPIs. We called KPIs in a HEN the heat duty $(\mathrm{Q})$, and the effectiveness $(\varepsilon)$ and J-indicator. Monitoring of these KPIs, ensure to know the real condition of each Heat exchanger in HEN and to take actions in the right moment. KPIs are time-dependent and are indirectly measured. Below are the models used

\section{A. Crude-oil Properties}

Due to the changes in crude oil temperature, is needed to takes models for the estimation of properties of crude oil. The models proposed by Polley [23] have been used in previous studies [4]; however, the correlations presented by Tajudin [18] fits better to the properties of the crude oil used in the study. The correlations for density, viscosity, and specific heat are shown in (1), (2) and (3) respectively, where $\mathrm{x}$ is the temperature in Celsius degrees.

$$
\begin{gathered}
\rho=(-0.6578 x+896.84) \times 0.0624279606 \\
\mu=\left\{\begin{array}{c}
16649 x^{-1.873} ; 24 \leq x \leq 66 \\
8050.9 x^{-1.708} ; 79 \leq x \leq 191 \\
14.356 x^{-0.014} ; 203 \leq x \leq 344
\end{array}\right. \\
C_{p}=(3 x+1940) \times 0.00023884589663
\end{gathered}
$$

\section{B. KPI's Calculation}

Kern and Seaton correlation [13], [31]-[33] presented in eq.(4), fits the fouling behavior of the heat exchanger in the study. This correlation allows only with time and an asymptotic value, the diagnosis, and prediction of fouling in a heat exchanger.

$$
R_{f}(t)=R_{f}^{\infty}(1-\exp (-t / \tau))
$$

Where $\tau$, called decay time, is calculated empirically, taking into account the behavior of each heat exchanger. $t$ is the time elapsed since the last maintenance in days. $R_{f}^{\infty}$ is the asymptotic fouling resistance, which depends on the speed of the fluid, the diameter of the tube, etc. This value can be taken from the TEMA standards [33], [34, Secs. 10-29] or it can be adjusted for each exchanger empirically, as has been done in this study.

To calculate the actual overall heat transfer coefficient, the model presented in eq.(5) is used, according to the literature [16], [33]. For the actual heat duty eq. (6) is used [16], [33], [35, p. 680]. This parameter allows to evaluate the real thermal load of the equipment with the current conditions, and thus be able to compare with the design conditions and those expected by the client. CLMTD is the product between the $\Delta T_{l m}$ and a correction factor eq. (7) [16], [33], [35, pp. 680-681]. The logarithmic mean temperature is showed in eq. (8) [16], [33].

$$
\begin{gathered}
U_{f}(t)=\frac{1}{\frac{1}{U_{d}}+R_{f}(t)} \\
\dot{Q}(t)=U_{f}(t) \times A \times C L M T D \\
C L M T D=F \times \Delta T_{l m} \\
\Delta T_{l m}=\frac{\left(T_{h, i}-T_{c, o}\right)-\left(T_{h, o}-T_{c, i}\right)}{\ln \left(\frac{T_{h, i}-T_{c, o}}{T_{h, o}-T_{c, i}}\right)}
\end{gathered}
$$

The heat flow calculation is then performed with the following equation eq. (7), where $\mathrm{F}$ is a correction factor, which is taken from the design data of each exchanger for this study.

$$
Q_{\text {actual }}=U A F \Delta T_{l m}
$$

To calculate effectiveness as the ratio between the current heat flux and the maximum possible heat flux. According to Yeap et al. [1], this is the most convenient method for heat exchanger networks. 


$$
Q_{\max }=C_{\min }\left(T_{h, i n}-T_{c, i n}\right)
$$

where:

$$
\begin{gathered}
C_{\min }=\dot{m}_{h} C_{p h} \leftrightarrow \dot{m}_{h} C_{p h}<\dot{m}_{c} C_{p c} \\
\vee \dot{m}_{c} C_{p c} \leftrightarrow \dot{m}_{c} C_{p c}<\dot{m}_{h} C_{p h} \\
\varepsilon=\frac{Q_{\text {actual }}}{Q_{\max }}
\end{gathered}
$$

For the calculation of the KPI called maintenance justification, current heat flow is compared with reference heat flow, on the cost of the maintenance effort to recover the reference condition. Where $\mathrm{C}_{\text {heat }}$ lost is the cost of BTU / hr not transferred, and Cmaint is the sum of all costs associated with maintenance.

$$
J=\frac{\left(Q_{\text {ref }}-Q_{\text {actual }} \times C_{\text {heat }}\right.}{\sum C_{\text {maint }}}
$$

\section{RESULTS}

The case is a real HEN in a crude oil distillation unit. The HEN is composed of fifteen heat exchangers, in a series/parallel combination shown in Fig. 1. Each heat exchanger in the network is intervened for maintenance once every year, which generates over-costs for unnecessary maintenance (over-

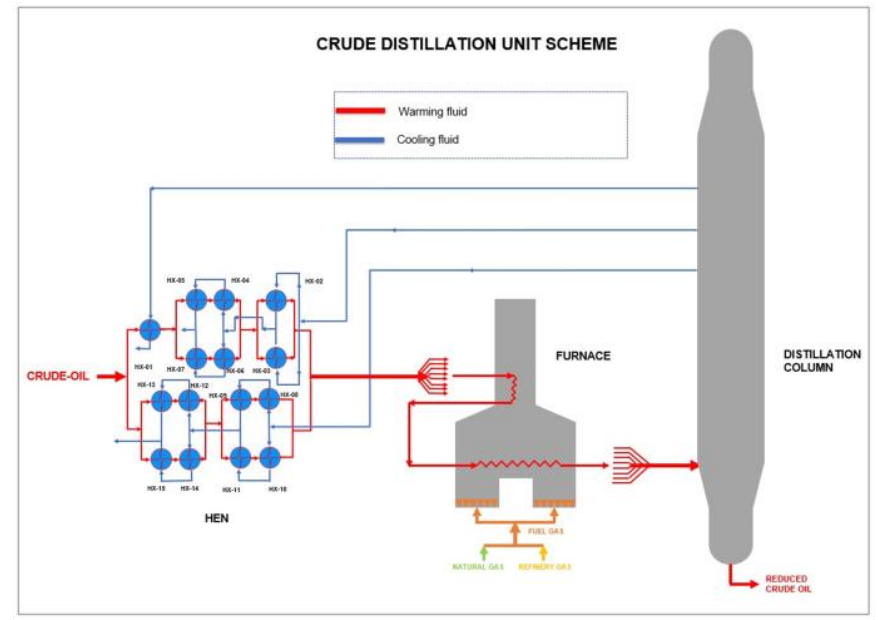

Fig. 1. HEN of the Crude distillation unit in study. Red lines represent the warming fluids, crude-oil in al cases. Blue lines represent the cooling fluids, them are different crude-oil products.

maintenance). Improvement/change of operating conditions is not allowed by the company in charge of the operation of the unit, so, this is not taken into account in the study. Thus, evaluation of KPI's it is the best way to evaluate maintenance interventions of HEN, with the resources at hand.

The Energy efficiency centered maintenance (ECM) model was implemented in a Computer Tool (CT) that performs the calculations with real-time data and can execute the procedure simultaneously for all the heat exchanger network exchangers of the crude distillation unit (Fig. 1). It allows us to evaluate the

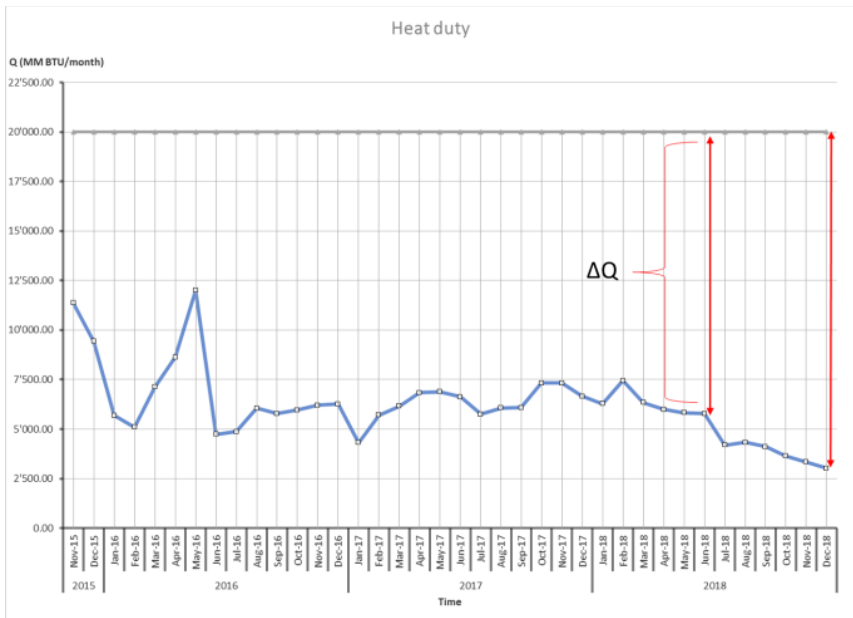

Fig. 4. Difference between reference heat duty (gray line) and current heat flow of a heat exchanger. correlation [13].

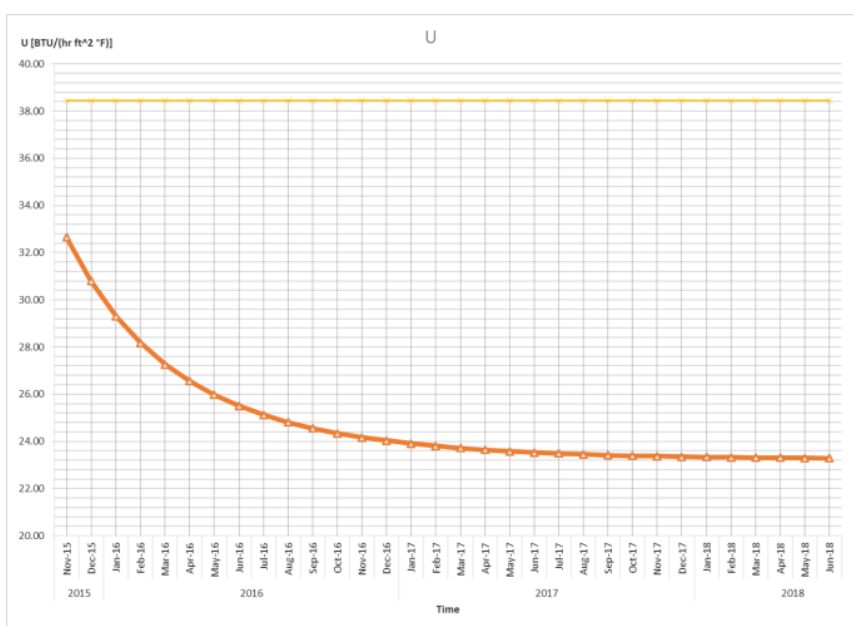

Fig. 3. Global heat transfer coefficient Trend. Yellow line reference, orange line actual trend.

quality of the maintenance performed. The implementation of this ECM CT in previously selected exchangers is shown below. Fig. 2 indicates the behavior of the heat exchanger fouling. Fig. 3 shows a decrease in the global heat transfer coefficient.

On the other hand, it can be seen in Fig. 4, as with time, the difference between the reference heat flow (or that expected by the customer), and the actual heat flow increases. It is in this difference that the justification of maintenance is evidenced, since the higher the difference, the lower the effectiveness of the heat exchange (Fig. 5), and the higher the costs of the fuel burned in the furnace. That is, to produce the same amount, must spend more money.

The business management calculates how much the heat transfer capacity lost in the network of heat exchangers costs, verifies how much maintenance costs (which can result in different degrees of cleaning), and if It is necessary to perform maintenance or not. This rate (KPI) is what was previously 
called J.

\begin{tabular}{|c|c|c|c|c|c|c|c|c|c|c|c|c|}
\hline \multicolumn{7}{|c|}{ EFFICIENCY CENTERED MAINTENANCE SCHEDULE - CDU-HEN } \\
\hline TIME & \multicolumn{3}{|c|}{2019} & \multicolumn{7}{|c|}{2019} & \multicolumn{3}{|c|}{2020} \\
\hline HX & IQ & IIQ & IIIQ & IVQ & IQ & IIQ & IIIQ & IVQ & IQ & IIQ & IIIQ & IVQ \\
\hline$H X-01$ & & & & & & & & & & JUL & & \\
\hline$H X-02$ & & & & & MAY & & & & & & & \\
\hline$H X-03$ & & & & & JUN & & & & & & & \\
\hline$H X-04$ & & & & NOV & & & & & & & & \\
\hline$H X-05$ & & & & NOV & & & & & & & & \\
\hline$H X-06$ & & & & DEC & & & & & & & & \\
\hline$H X-07$ & & & & DEC & & & & & & & & \\
\hline$H X-08$ & & & & & & & & & JAN & & & \\
\hline$H X-09$ & & & & & & & & & MAR & & & \\
\hline$H X-10$ & & & & & & & & & & & SEP & \\
\hline$H X-11$ & & & & & & & & & & & & NOV \\
\hline
\end{tabular}

Fig. 6. Maintenance schedule of a network of heat exchangers, planned with the proposed methodology.

Using a criticality matrix, which was based on the proposal by Francisco Gonzalez [36], the maintenance engineer plans the intervention of each team, based on the criticality obtained. Fig. 6 shows one of the maintenance programs carried out with this methodology, which achieved savings of USD 150,000.

\section{CONCLUSION}

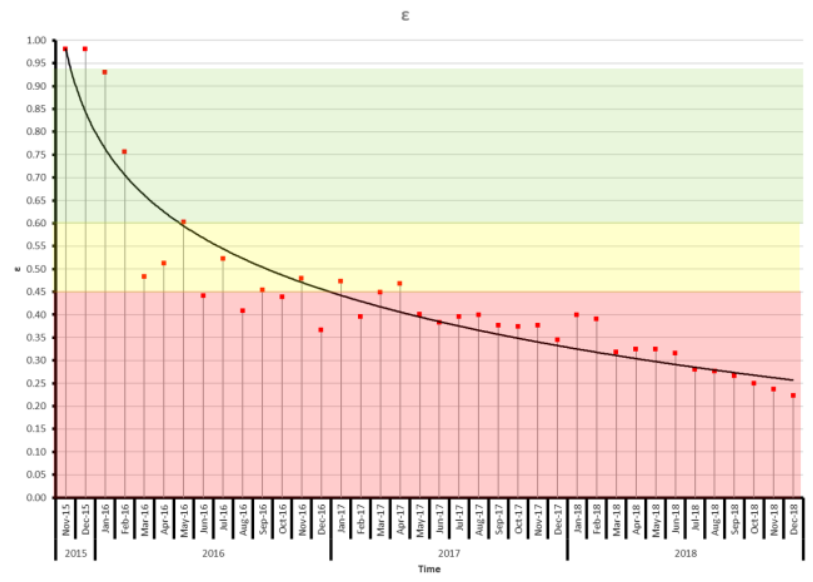

Fig. 5. Effectiveness trend of a heat exchanger

The MCE has an Economic Justification Indicator $(\mathrm{J})$ that relates the economic-energy improvement that is achieved when performing maintenance taking into account the economic effort invested. Depending on the type of maintenance to be performed (its cost), a threshold must be chosen, from which the maintenance activity is justified. This must be a managerial decision, taken taking into account market fluctuations and company policies.

The values of the effectiveness of the heat exchanger $(\varepsilon)$ and the $\mathrm{J}$ Factor are used to elaborate the criticality of each exchanger.

The planning of the dates of execution of the maintenance of each heat exchanger, from the ECM applied to the preheating train of the crude distillation unit constitutes a contribution in this specific field. The conceptual design of the ECM presented in this work, is feasible to apply to other equipment energy transformation, used in oil refineries and industry in general.

\section{REFERENCES}

[1] B. L. Yeap, D. I. Wilson, G. T. Polley, and S. J. Pugh, "Mitigation of crude oil refinery heat exchanger," Chem. Eng., vol. 82, no. January, pp. 53-71, 2004.

[2] M. R. Jafari Nasr and M. Majidi Givi, "Modeling of crude oil fouling in preheat exchangers of refinery distillation units," Appl. Therm. Eng., vol. 26, no. 14-15, pp. 1572-1577, 2006, DOI: 10.1016/j.applthermaleng.2005.12.001.

[3] A. Hoang, P. Do, and B. Iung, "Energy efficiency performance-based prognostics for aided maintenance decision-making: Application to a manufacturing platform," J. Clean. Prod., vol. 142, pp. 2838-2857, 2017, DOI: 10.1016/j.jclepro.2016.10.185.

[4] J. Tian, Y. Wang, and X. Feng, "Simultaneous optimization of flow velocity and cleaning schedule for mitigating fouling in refinery heat exchanger networks," Energy, vol. 109, pp. 1118-1129, 2016, DOI: 10.1016/j.energy.2016.05.053.

[5] M. C. Georgiadis and L. G. Papageorgiou, "Optimal energy and cleaning management in heat exchanger networks under fouling," Chem. Eng. Res. Des., vol. 78, no. 2, pp. 168-179, 2000, DOI: $10.1205 / 026387600527194$.

[6] M. C. Georgiadis, L. G. Papageorgiou, and S. Macchietto, "Optimal Cleaning Policies in Heat Exchanger Networks under Rapid Fouling," Ind. Eng. Chem. Res., vol. 39, no. 2, pp. 441-454, Feb. 2000, DOI: 10.1021/ie990166c

[7] S. M. Zubair, A. K. Sheikh, M. Younas, and M. O. Budair, "A risk based heat exchanger analysis subject to fouling Part I: Performance evaluation," Energy, vol. 25, pp. 427-443, 2000, DOI: DOI: 10.1016/s0360-5442(99)00080-8.

[8] C. Rodriguez and R. Smith, "Optimization of operating conditions for mitigating fouling in heat exchanger networks," Chem. Eng. Res. Des., vol. 85, no. 6 A, pp. 839-851, 2007, DOI: 10.1205/cherd06046.

[9] A. K. Sheikh, S. M. Zubair, M. Younas, and M. O. Budair, "A risk based heat exchanger analysis subject to fouling: Part II: Economics of heat exchangers cleaning," Energy, vol. 25, no. 5, pp. 445-461, 2000, DOI: 10.1016/S0360-5442(99)00081-X.

[10] F. Smaili, V. S. Vassiliadis, and D. I. Wilson, "Mitigation of fouling in refinery heat exchanger networks by optimal management of cleaning," Energy Fuels, vol. 15, no. 5, pp. 1038-1056, 2001, DOI: 10.1021/ef010052p.

[11] E. M. Ishiyama, W. R. Paterson, and D. I. Wilson, "Thermo-hydraulic channelling in parallel heat exchangers subject to fouling," Chem. Eng. Sci., vol. 63, no. 13, pp. 3400-3410, 2008, DOI: 10.1016/j.ces.2008.04.008.

[12] A. J. Waters, C. G. Akinradewo, and D. Lamb, "Fouling: Implementation of a Crude Preheat Train Performance Monitoring Application at the Irving Oil Refinery," Int. Conf. Heat Exch. Fouling Clean. VIII, vol. 2009, pp. 33-38, 2009.

[13] A. C. Caputo, P. M. Pelagagge, and P. Salini, "Joint economic optimization of heat exchanger design and maintenance policy," Appl. Therm. Eng., vol. 31, no. 8-9, pp. 1381-1392, 2011, DOI: 10.1016/j.applthermaleng.2010.12.033.

[14] Y. Wang, M. Pan, I. Bulatov, R. Smith, and J. K. Kim, "Application of intensified heat transfer for the retrofit of heat exchanger network," Appl. Energy, vol. 89, no. 1, pp. 45-59, 2012, DOI: 10.1016/j.apenergy.2011.03.019.

[15] B. C. G. Assis et al., "Constrained thermohydraulic optimization of the flow rate distribution in crude preheat trains," Chem. Eng. Res. Des., vol. 91, no. 8, pp. 1517-1526, 2013, DOI: 10.1016/j.cherd.2013.06.005.

[16] T. R. Biyanto, M. Ramasamy, A. B. Jameran, and H. Y. Fibrianto, "Thermal and hydraulic impacts consideration in refinery crude preheat train cleaning scheduling using recent stochastic optimization methods," Appl. Therm. Eng., vol. 108, no. 5, pp. 1436-1450, Sep. 2016, DOI: 10.1016/j.applthermaleng.2016.05.068.

[17] E. Diaz-Bejarano, F. Coletti, and S. Macchietto, "Modeling and Prediction of Shell-Side Fouling in Shell-and-Tube Heat Exchangers," Heat Transfer Engineering, 2018.

[18] Z. Bin Tajudin, "Experiments, Modelling and Validation of Crude Oil Fouling on Large Scale Rig,” Imperial College London, 2015. 
[19] E. Davoudi and B. Vaferi, "Chemical Engineering Research and Design Applying artificial neural networks for systematic estimation of degree of fouling in heat exchangers," Chem. Eng. Res. Des., vol. 130, pp. 138153, 2017, DOI: 10.1016/j.cherd.2017.12.017.

[20] W. Ebert and C. B. Panchal, "Analysis of Exxon crude-oil-slip stream coking data," in Fouling mitigation of industrial heat exchangers, 1995, pp. 18-23, URL: https://www.osti.gov/servlets/purl/453433.

[21] D. K. Mohanty and P. M. Singru, "Use of C-factor for monitoring of fouling in a shell and tube heat exchanger," Energy, vol. 36, no. 5, pp. 2899-2904, 2011, DOI: 10.1016/j.energy.2011.02.032.

[22] S. K. Ogbonnaya and O. O. Ajayi, "Fouling phenomenon and its effect on heat exchanger: A review," Front. Heat Mass Transf., vol. 9, pp. 2007-2018, 2017, DOI: 10.5098/hmt.9.31.

[23] G. T. Polley, D. I. Wilson, B. L. Yeap, and S. J. Pugh, "Evaluation of laboratory crude oil threshold fouling data for application to refinery pre-heat trains," in Applied Thermal Engineering, 2002, vol. 22, no. 7, pp. 777-788, DOI: 10.1016/S1359-4311(02)00023-6.

[24] D. I. Wilson, G. T. Polley, and S. J. Pugh, "Ten Years of Ebert, Panchal and the 'Threshold Fouling' Concept," in 6th International Conference on Heat Exchanger Fouling and Cleaning - Challenges and Opportunities, 2005, pp. 25-36.

[25] D. I. Wilson, E. M. Ishiyama, and G. T. Polley, "Twenty Years of Ebert and Panchal-What Next?," Heat Transf. Eng., vol. 38, no. 7-8, 2017, DOI: $10.1080 / 01457632.2016 .1206407$.

[26] N. Shetty, U. B. Deshannavar, R. Marappagounder, and R. Pendyala, "Improved threshold fouling models for crude oils," Energy, vol. 111, pp. 453-467, 2016, DOI: 10.1016/j.energy.2016.05.130.

[27] F. Smaïli, V. S. Vassiliadis, and D. I. Wilson, "Optimization of cleaning schedules in heat exchanger networks subject to fouling," Chem. Eng. Commun., vol. 189, no. 11, pp. 1517-1549, 2002, DOI: 10.1080/00986440214999.

[28] F. Smaïli, V. S. Vassiliadis, and D. I. Wilson, "Long-term scheduling of cleaning of heat exchanger networks: Comparison of outer approximation-based solutions with a backtracking threshold accepting algorithm," Chem. Eng. Res. Des., vol. 80, no. 6, pp. 561-578, Sep. 2002, DOI: $10.1205 / 026387602760312764$.

[29] J. L. Borges, E. M. Queiroz, F. L. P. Pessoa, F. S. Liporace, S. G. Oliveira, and A. L. H. Costa, "Fouling management in crude oil preheat trains through stream split optimization," in Computer Aided Chemical Engineering, 2009, vol. 27, no. C, pp. 1587-1592, DOI: 10.1016/S1570-7946(09)70655-8.

[30] L. O. de Oliveira Filho, F. S. Liporace, E. M. Queiroz, and A. L. H. Costa, "Investigation of an alternative operating procedure for fouling management in refinery crude preheat trains," Appl. Therm. Eng., vol. 29, no. 14-15, pp. 3073-3080, 2009, DOI: 10.1016/j.applthermaleng.2009.04.012.

[31] D. Kern and R. Seaton, "A theoretical analysis of thermal surface fouling," Br Chem Eng, vol. 4, pp. 258-262, 1959.

[32] G. T. Polley, D. I. Wilson, B. L. Yeap, and S. J. Pugh, "Use of crude oil fouling threshold data in heat exchanger design," in Applied Thermal Engineering, 2002, vol. 22, no. 7, pp. 763-776, DOI: 10.1016/S13594311(02)00021-2.

[33] S. Sanaye and B. Niroomand, "Simulation of heat exchanger network (HEN) and planning the optimum cleaning schedule," Energy Convers. Manag., vol. 48, no. 5, pp. 1450-1461, 2007, DOI: 10.1016/j.enconman.2006.12.006.

[34] Tubular Exchanger Manufacturers Association Inc, Standard of the Tubular Exchanger Manufacturers Association, Ninth Edition. 2007.

[35] Y. A. Cengel, Heat Transfer A practical Approach, 2nd ed. 2003.

[36] F. J. González Fernández, Auditoría del mantenimiento e indicadores de gestión, 1st ed. Madrid, España: Fundación Confemetal, 2004.

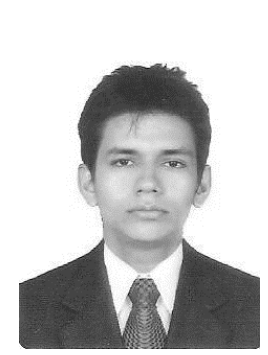

Daniel E. Yabrudy Mercado was born in Cartagena de Indias, Bolívar, Colombia in 1991. He received the B.S. in mechatronic engineering from the Universidad Tecnológica de Bolívar, Cartagena de Indias, in 2013 and is candidate for a master's degree in the same university. From 2011 to 2012, he was a Research Assistant with the thermal conductivity laboratory. Since 2018 he in the master program. Since 2019 he has been an Assistant Professor with the Facultad de ingeniería mecanica, electronica $y$ biomedical (FIMEB) at the Universidad Antonio Nariño sede Cartagena.

ORCID: https://orcid.org/0000-0002-8161-8077

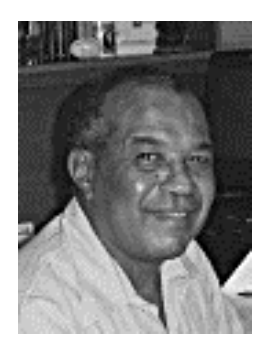

Bienvenido Sarria López Sarria was born in Cuba in 1952. He received the B.S in mechanical engineer from the Universidad Central de las Villas, Cuba in 1978, master degree in energy efficiencies from the Universidad de Cienfuegos, Cuba in 1997 and $\mathrm{PhD}$. degree in Technical Sciences from the same university in 1999. Work areas: Energy Efficiency and Thermal Design. Clean Production. Optimization of Combustion and Heat Exchange processes. Boilers.

ORCID: https://orcid.org/0000-0001-9209-4603

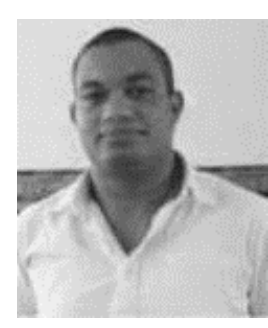

Juan G. Fajardo Cuadro was born in Cartagena de Indias, Bolívar, Colombia in 1976. He received the B.S. in mechatronic engineering from the Universidad Tecnológica de Bolívar, Cartagena de Indias - Colombia, in 1999, master degree in mechanical engineer from the Universidad de los Andes, Bogotá Colombia in 2003 and $\mathrm{PhD}$. degree in Technical Sciences from Universidad de Cienfuegos, Cuba in 2016. He is currently an associate professor with the Universidad Tecnológica de Bolívar. Work areas: Thermoeconomic analysis of air conditioning systems in naval and river ships. Energy and thermoeconomic diagnoses of thermal power plants and boilers. Maintenance and energy analysis of internal combustion engines.

ORCID: https://orcid.org/0000-0002-5675-7796

Camilo A. Cardona Agudelo was born in Medellin, Antioquia, Colombia in 1974. He received the B.S. in mechatronic engineering from the Universidad Tecnológica de Bolívar, Cartagena de Indias - Colombia, in 1999. He has extensive experience in the oil and gas sector, working as a reliability engineer, maintenance engineer, and maintenance manager, developing asset management strategies based on reliability and energy efficiency.

ORCID: https://orcid.org/0000-0002-1736-8157 